\begin{tabular}{c|c|c}
\hline \hline Vol. 14: 161-173, 2000 & CLIMATE RESEARCH \\
Clim Res & Published May 2 \\
\hline \hline
\end{tabular}

\title{
The Mid-A tlantic Region and its climate: past, present, and future
}

\section{Colin Polsky*, J ason Allard, N ate C urrit, Robert C rane, Brent Yarnal}

Department of G eography and Earth System Science Center, The Pennsylvania State University, University Park, Pennsylvania 16802, USA

\begin{abstract}
The physical and human geographies and the historical climate of the Mid-Atlantic Region of the United States are described to provide a baseline for an ongoing assessment of likely climate change impacts in the region. This region consists of 358 counties intersecting part or all of 8 states and 4 physiographic zones. This geographic diversity provides different sets of options for societies to adapt to environmental changes. Since 1967, the region's human population has grown in both number (19\%) and income (116\%), and important local ecosystems are experiencing associated stresses. Since 1895 , the region's climate has become slightly warmer $\left(+0.5^{\circ} \mathrm{C}\right)$ and significantly wetter $(+10 \%)$, although the warming has abated recently. Projections indicate that these broad regional socio-economic, ecological and climatic trends should persist through the 21st century. The significance of these changes in society, ecosystems and climate are evaluated in the more detailed, sectorspecific analyses in the subsequent articles of this Special.
\end{abstract}

KEY WORDS: Climate change - Climate variation - Climate scenarios - Socio-economic change · Mid-Atlantic Region

\section{INTRODUCTION}

In its simplest form, the assessment of the regional impacts from climate change is a 3-step process. First, a baseline scenario is established where the contemporary status of the natural and human environments is assessed and extrapolated into the future, assuming that no climate change will occur. Second, prescribed changes in climate are imposed on the baseline account. Third, climate change impacts on the baseline variables are estimated by calculating the differences between the no climate change scenario and the changed climate scenario, at which point they are evaluated for significance. (A more detailed account of this process can be found in Carter et al. [1994].) This article contributes to the first and second steps of an ongoing assessment of likely climate change impacts for the Mid-Atlantic Region (MAR) of the United States. The subsequent articles in this Special provide the more detailed sector-specific analyses necessary to achieve the third step. The basic physical and human geographies of the MAR and their evolution over the

*E-mail: polsky@essc.psu.edu past 3 decades are summarized in Section 2, the historical climate is outlined in Section 3, scenarios of future climate are developed in Section 4, and a conclusion is presented in Section 5.

\section{GEOGRAPHY OF THE MAR}

The MAR as defined for this assessment (Fig. 1) includes all of 5 states (Delaware, Maryland, Pennsylvania, Virginia, West Virginia), parts of 3 states (south-central New York, western and southern New J ersey, northeastern N orth Carolina), and the District of Columbia. In all, the MAR covers about $5 \%$ of the land area in the 48 contiguous US (Bureau of the Census 1997).

\subsection{Physical geography}

The M A R contains 358 counties intersecting 4 principal physiographic regions oriented along a northeastsouthwest axis (Cuff et al. 1989). On the eastern edge, there is the relatively flat Coastal Plain, composed mostly of sedimentary rock and extending inland from the 


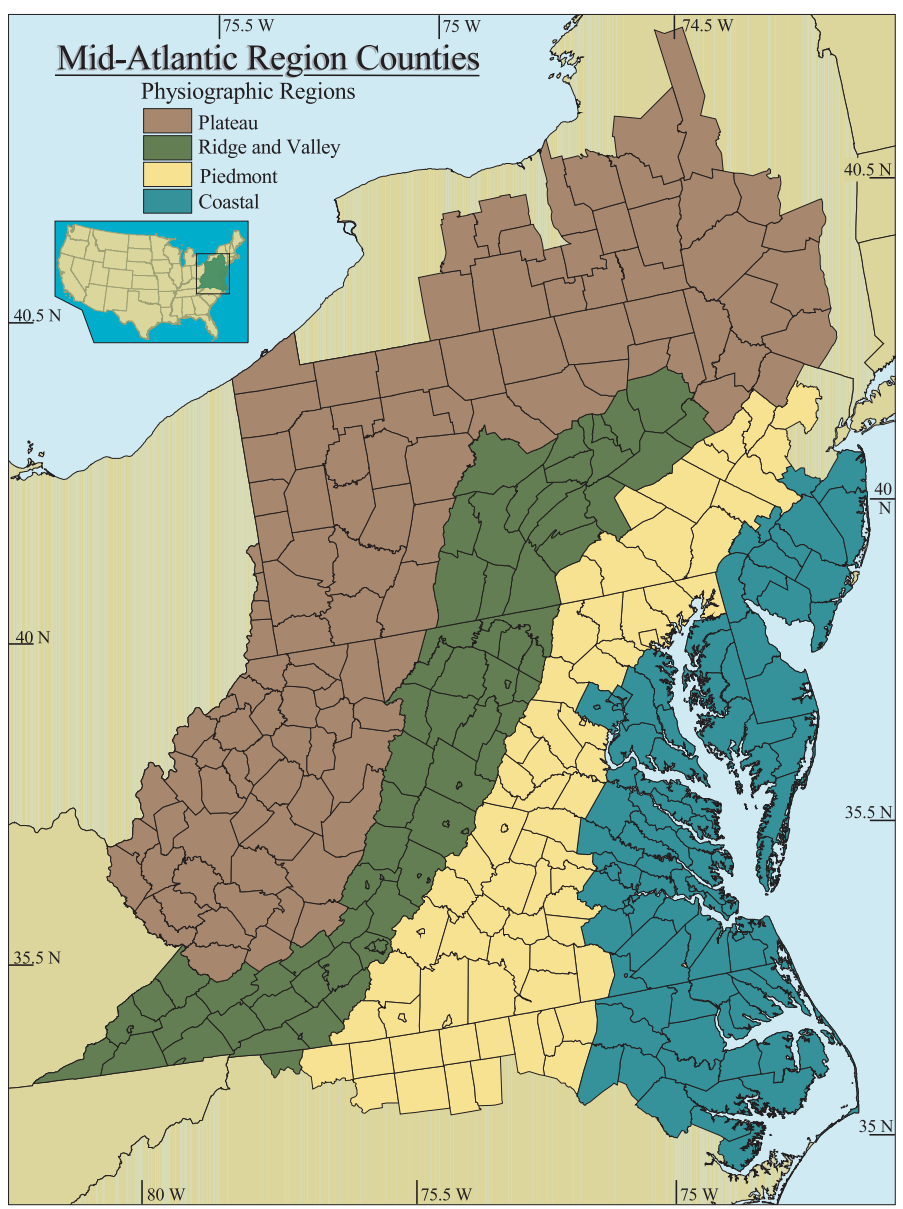

Fig. 1. Mid-Atlantic Region (MAR) counties and physiographic regions

oceans and estuaries. This zone traverses all of Delaware and parts of New J ersey, M aryland, Virginia, and North Carolina. The Piedmont is the foothills region covering the eastern, lower portion of the A ppalachian mountain range. This area is composed mostly of metamorphic and igneous rock, and covers north-central New J ersey, southeastern Pennsylvania and the central portions of M aryland, Virginia and North Carolina. The Ridge and Valley zone contains primarily sedimentary rocks and exhibits folded terrain with a series of parallel, eroded mountains of equal height. This strip of land extends from the northwest corner of N ew J ersey to the southwest, passing through Pennsylvania, Maryland and Virginia. The A ppalachian Plateau is a complex swath of land extending from the New York portion of the MAR through north-central and western Pennsylvania, the western edge of Maryland and most of West Virginia. This region is composed of rolling hills in places and relatively flat sedimentary rock in others, dissected throughout by meandering waterways (Cuff et al. 1989, M arsh \& Lewis 1995).
Land use and land cover in the MAR are largely defined by forest and agricultural activities (EPA 1997). As shown in Table 1, these 2 categories account for about $90 \%$ of regional land cover. The highest concentrations of forest area are in and around West Virginia and north-central Pennsylvania. Agriculture is the predominant land use in the lowlands to the east.

The ecological health of M AR water bodies is in flux because local activities associated with economic development are generating pollution. For example, 2 significant sources of aquatic pollution (agriculture operations and roads located near streams) are found in many regional watersheds (EPA 1997). A mong the ecologically important areas of the region are the nation's 2 largest estuaries, the Chesapeake Bay and Albermarle-Pamlico Sound. For the Chesapeake Bay, twothirds of its nutrient and sediment loading come from upstream, non-point pollution sources. This is of particular concern given the Bay's $350 \mathrm{~d}$ flushing rate, one of the slowest for a water body in the US (NOAA 1998).

\subsection{Human geography}

Broad economic and demographic characteristics of the MAR are provided here, by physiographic subregion for the year 1995 (Table 2 ) and for the region as a whole for the past 3 decades (Table 3). As indicated in Table 2, in 1995 the M AR had a population of 35.2 million people, 20 million of whom were employed, earning a collective income of $\$ 859$ billion (NPA 1998a). These figures represent in each case about $15 \%$ of the respective US totals (Bureau of the Census 1998a), about 3 times the expected rate based on land area alone. Nearly $90 \%$ of the MAR population is under the age of 65. Close to two-thirds of the total working-age population, income and jobs are found in the eastern half of the region, i.e. the Coastal Plain and Piedmont. This eastern weighting translates into a markedly higher per capita income for these 2 sub-regions compared to the Ridge and Valley and Appalachian Plateau, and is associated with the relative prominence of urbanization and high value-added sectors there.

Table 1. Land use in the Mid-Atlantic Region (MAR), 1992. Source: MARA (1999)

\begin{tabular}{|lc|}
\hline Land use category & $\begin{array}{c}\text { Percentage of } \\
\text { total land area }\end{array}$ \\
\hline Forest & 64.5 \\
Agriculture & 25.0 \\
Wetlands & 4.1 \\
Commercial, industrial, and residential & 3.6 \\
Open water & 1.6 \\
All other land uses & 1.2 \\
\hline
\end{tabular}


Table 2. Geographic distribution of important socio-economic variables for the MAR, 1995 (percent and value). Source: NPA (1998a)

\begin{tabular}{|c|c|c|c|c|c|}
\hline & $\begin{array}{l}\text { Coastal } \\
\text { Plain }\end{array}$ & Piedmont & $\begin{array}{l}\text { Ridge and } \\
\text { Valley }\end{array}$ & $\begin{array}{l}\text { Appalachian } \\
\text { Plateau }\end{array}$ & Total \\
\hline $\begin{array}{l}\text { Population } \\
\text { (million people) }\end{array}$ & $\begin{array}{l}36 \% \\
12.7\end{array}$ & $\begin{array}{l}29 \% \\
10.1\end{array}$ & $\begin{array}{l}10 \% \\
3.5\end{array}$ & $\begin{array}{c}25 \% \\
8.9\end{array}$ & $\begin{array}{c}100 \% \\
35.2\end{array}$ \\
\hline Age 0-19 & $\begin{array}{l}37 \% \\
3.5\end{array}$ & $\begin{array}{l}28 \% \\
2.7\end{array}$ & $\begin{array}{l}9 \% \\
0.9\end{array}$ & $\begin{array}{l}25 \% \\
2.4\end{array}$ & $\begin{array}{l}100 \% \\
9.5\end{array}$ \\
\hline Age $20-64$ & $\begin{array}{l}37 \% \\
7.6\end{array}$ & $\begin{array}{c}29 \% \\
6.1\end{array}$ & $\begin{array}{l}10 \% \\
2.0\end{array}$ & $\begin{array}{c}25 \% \\
5.1\end{array}$ & $\begin{array}{c}100 \% \\
20.8\end{array}$ \\
\hline Age 65+ & $\begin{array}{c}33 \% \\
1.6\end{array}$ & $\begin{array}{c}27 \% \\
1.3\end{array}$ & $\begin{array}{l}10 \% \\
0.5\end{array}$ & $\begin{array}{c}29 \% \\
1.4\end{array}$ & $\begin{array}{c}100 \% \\
4.8\end{array}$ \\
\hline $\begin{array}{l}\text { Income } \\
\text { (billion 1995\$) }\end{array}$ & $\begin{array}{l}38 \% \\
\$ 327\end{array}$ & $\begin{array}{l}32 \% \\
\$ 277\end{array}$ & $\begin{array}{l}8 \% \\
\$ 70\end{array}$ & $\begin{array}{l}22 \% \\
\$ 186\end{array}$ & $\begin{array}{l}100 \% \\
\$ 859\end{array}$ \\
\hline $\begin{array}{l}\text { Income per } \\
\text { capita (1995\$) }\end{array}$ & $\$ 25794$ & $\$ 27450$ & $\$ 19852$ & $\$ 20812$ & $\$ 24417$ \\
\hline $\begin{array}{l}\text { Total employment } \\
\text { (million jobs) }\end{array}$ & $\begin{array}{c}38 \% \\
7.5\end{array}$ & $\begin{array}{c}30 \% \\
5.9\end{array}$ & $\begin{array}{c}10 \% \\
1.9\end{array}$ & $\begin{array}{c}23 \% \\
4.5\end{array}$ & $\begin{array}{c}100 \% \\
19.7\end{array}$ \\
\hline $\begin{array}{l}\text { Total farm employment } \\
\text { (thousand jobs) }\end{array}$ & $\begin{array}{c}19 \% \\
48\end{array}$ & $\begin{array}{c}30 \% \\
77\end{array}$ & $\begin{array}{c}21 \% \\
53\end{array}$ & $\begin{array}{l}30 \% \\
76\end{array}$ & $\begin{array}{c}100 \% \\
254\end{array}$ \\
\hline
\end{tabular}

While large cities do not cover much of the M AR surface area, collectively they constitute one of the more important population concentrations in the country. Of the MAR urban areas, Philadelphia, Pittsburgh, Baltimore, Washington, DC, Richmond, and Norfolk are among the largest cities in the US. These cities alone have accounted for about one-half of the total MAR population since 1980 (Bureau of the Census 1998b, NPA 1998a).

The MAR population increased by approximately $20 \%$ between 1967 and 1995, a rate of about $0.7 \% \mathrm{yr}^{-1}$ on average (Table 3 ). This trend is slightly less pronounced than for the nation as a whole, which grew by $33 \%$ at a rate of $1 \% \mathrm{yr}^{-1}$ (Bureau of the Census 1998a). The MAR has experienced a steady increase $(1.2 \%$ $\mathrm{yr}^{-1}$ ) of working-age residents since the late 1960s, and a steady decrease $\left(0.6 \% \mathrm{yr}^{-1}\right)$ of people under the age of 20 , although in recent years this latter trend has reversed. By contrast, the elderly population in the MAR grew by about $70 \%$ during the same period $\left(2.6 \% \mathrm{yr}^{-1}\right)$.

Table 3. Changes in important socio-economic variables for the MAR, 1967 to 1995. Source: NPA (1998a)

\begin{tabular}{|lrc|}
\hline & $\begin{array}{c}\text { Total change } \\
(\%)\end{array}$ & $\begin{array}{c}\text { Average annual } \\
\text { change (\%) }\end{array}$ \\
\hline Total population & 19 & 0.7 \\
Age 0-19 & -16 & -0.6 \\
Age 20-64 & 34 & 1.2 \\
Age 65+ & 72 & 2.6 \\
Income & 116 & 4.1 \\
Income per capita & 82 & 2.9 \\
Total employment & 55 & 2.0 \\
Total farm employment & -42 & -1.5 \\
\hline
\end{tabular}

Aggregate income more than doubled over this period, and per capita income grew by $82 \%$ (Table 3 ). Income in the services sector recorded the largest growth over the period, over 300\% (NPA 1998a). Total employment has increased by more than half since 1967, fueled largely by non-farm industries such as services, which more than doubled over the period (NPA 1998a). By contrast, farm-related employment declined by almost one-half. As such, from an economic perspective agriculture in the MAR is becoming progressively less important over time, reflecting the broader national trend (Shane et al. 1998). For a more detailed description of the M AR economy, see Rose et al. (2000, in this issue).

\subsection{Coming decades}

This human geography baseline is not complete without an assessment of future conditions in the absence of climate change. There are many ways to project future values of the economic and demographic variables, and the resulting values can differ substantially, depending on the projection methodology employed. One set of projections for 3 key measures of regional socio-economic structure (population, employment, income) to the year 2050 is presented in Fig. 2. These projections reflect a 'baseline' scenario (i.e. where current trends are assumed to persist), and 'low' and 'high' scenarios (i.e. where current trends diminish and increase, respectively, in the coming decades). These projections are driven primarily by assumptions regarding the net distribution of birth, death, immigration and internal (US) migration rates, per capita income, and overall economic activity. For more details on the assumptions underlying these particular projections, see NPA (1998b).

Given the link between anthropogenic pollution and ecosystem health, the future status of regional ecosystems - also in the absence of climate changecan be estimated based in part on these socio-economic projections. However, these estimated ecosystem impacts also depend on the parameterization of the various society-ecosystem relationships; see Rogers \& McCarty (2000, in this issue) for an analysis of this topic. In the subsequent articles of this Special, the baseline socio-economic and ecological projections are modified to account for a given climate change (outlined in Section 4), and the resul- 

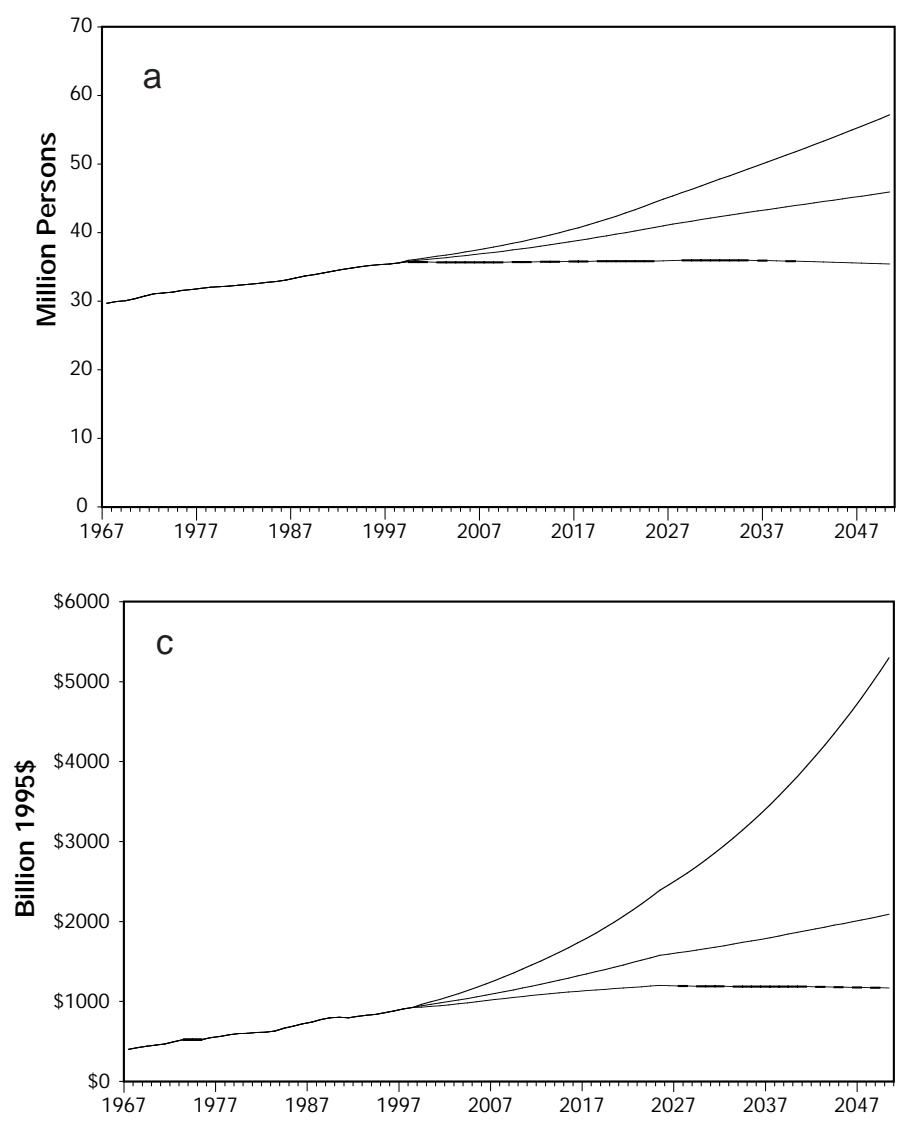

tant differences are evaluated for significance. The significance of this climate change impact will be conditioned by the adaptability of regional societies and ecosystems, which is in turn a function of historical climate.

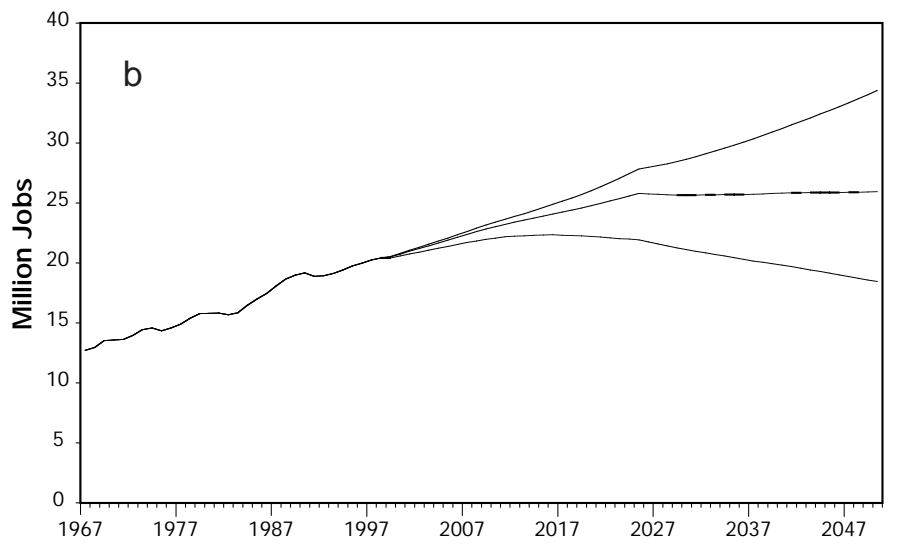

Fig. 2. Baseline, low- and high-growth scenarios for (a) population, (b) employment, and (c) income in the MAR, 1967 to 2050 (NPA 1998a)

\section{MAR CLIMATE}

Over the period 1895 to 1997, the mean annual temperature of the MAR was approximately $11^{\circ} \mathrm{C}$, while the mean monthly precipitation was about $87 \mathrm{~mm}$ (calculated from the data in Fig. 3). Temperature experienced a minor upward linear trend over the period $(y=$ $0.0024 x+10.828)$, which amounts to an increase of approximately $0.5^{\circ} \mathrm{C}$. A second-order polynomial fits the temperature data better than the linear trend line, however, and shows that there was an upward temperature trend in the first half of the data record but a downward temperature trend in the second half. Pre-
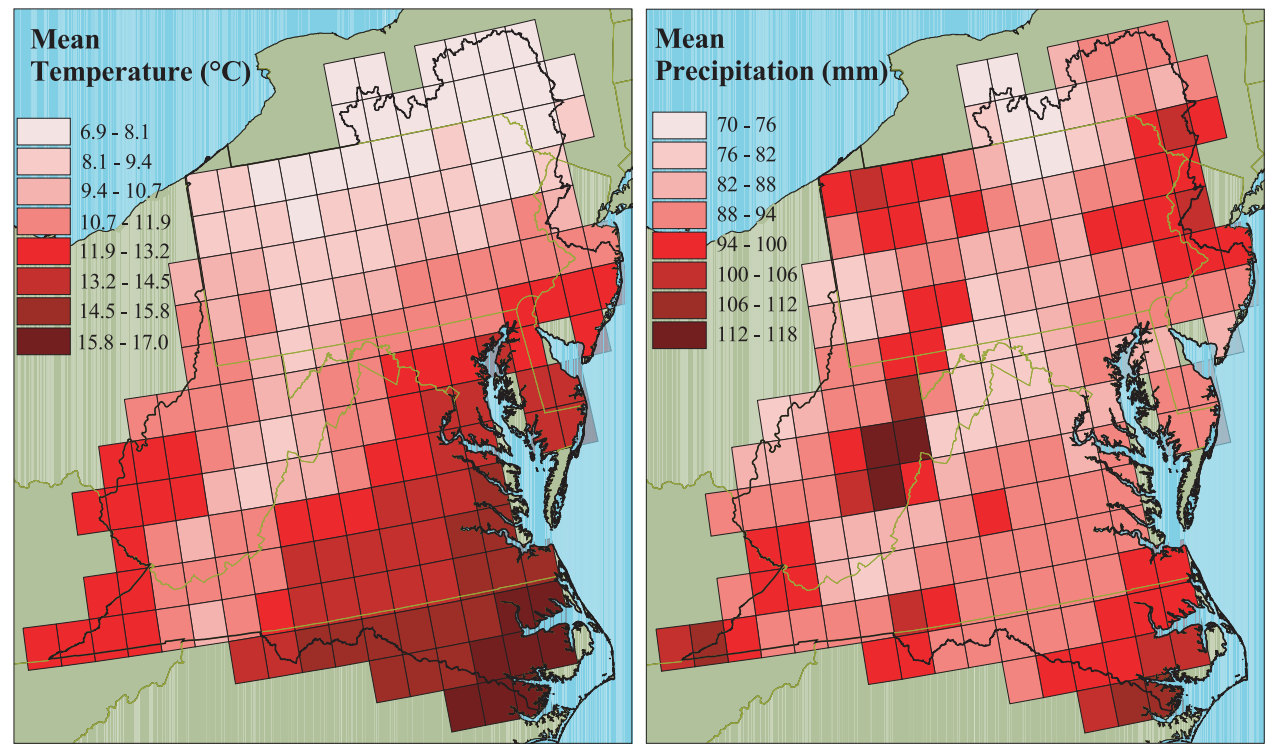

Fig. 3. Mean monthly temperature and mean monthly precipitation over the MAR. Data are from VEM AP (Kittel et al. 1995, Rosenbloom \& Kittel 1999) 
cipitation rose roughly $10 \%(y=0.0892 x+82.236)$; a linear trend fits the precipitation better than any loworder polynomial. Within these regional averages and trends, there were significant interannual and interdecadal variations, intra-regional trends, and counterintuitive changes in extremes.

\subsection{Recent climate variation}

There are clear relationships among the precipitation and temperature variations of the MAR (Fig. 4). In general, from the beginning of the record to about 1930, the climate was cool and dry. The early 1930s saw a couple of exceedingly hot, dry years associated with the Midwestern Dust Bowl. This short, sharp drought was followed by nearly 3 decades of relatively warm, moist climate. This period was in turn followed by a cool and very dry climate in the 1960s. In contrast, the 1970s were exceedingly wet, but varied between warm and cold. Since the late 1970s-early 1980s, precipitation and temperature have varied dramatically above and below the long-term mean.

The variations in MAR climate since World War II can be explained by changes in the atmospheric circulation. (Earlier periods lacked the upper-air data needed to make the following generalizations.) A zonal regime dominated the atmospheric flow over North America through the late 1940s and early 1950s (Yarnal \& Leathers 1988). Such a regime produced nor- mal to slightly above-normal temperatures and variable precipitation over the MAR. Then in the mid- to late 1950s, the circulation experienced a transition from zonal to meridional flow, becoming fully entrenched by the 1960s. During this decade, the MAR was influenced by an anomalous, deep trough of continental polar air and a storm track southeast of its long-term mean position, with precipitation often falling off the Atlantic coast. This regime promoted a relatively cool, dry climate. The early 1970s saw the continuation of this meridional regime, but the average position of the trough migrated westward, putting the storm track over the MAR. This change raised temperatures and caused a significant increase in precipitation. Finally, the mid- to late 1970s brought a large change in the atmospheric circulation. The period following this transformation -- which has extended to the present-- has been associated with unusually large variations in the shape and positioning of the month-to-month and year-to-year jet stream flow over North America. It is not possible to determine the direct causes of these intra- and inter-annual variations in circulation, but limited previous (e.g., Yarnal \& Leathers 1988) and ongoing work (e.g., Cronin 1997, Cronin et al. 2000) suggests associations between the variations and global-scale circulation anomalies, such as the PacificNorth American pattern and the North Atlantic Oscillation. On decadal scales, major shifts in the planetaryscale circulation were observed in the mid- to late 1950s (e.g., Kalnicky 1974, Balling \& Lawson 1982) and

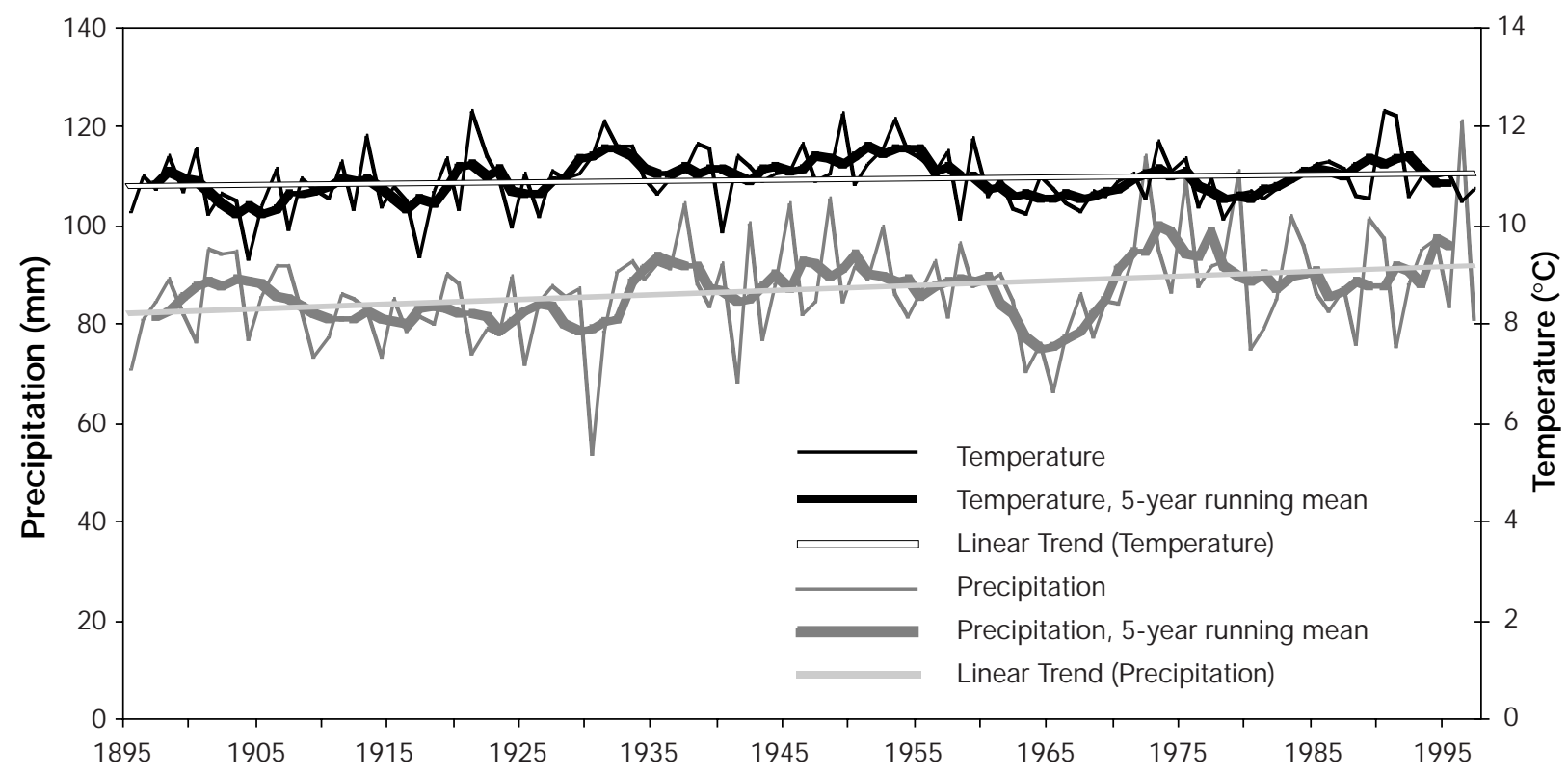

Fig. 4. Mean monthly precipitation ( $\mathrm{mm}$ ) and mean annual temperature $\left({ }^{\circ} \mathrm{C}\right.$ ) in the MAR, 1895 to 1997 . Thin line denotes average annual values, while the thick curving line is a 5 yr running mean and the thick straight line is a linear trend. For this analysis, the MAR is defined by the watershed boundaries of the Chesapeake and Delaware Bays (see Fig. 3 in Fisher et al. [2000, in this issue]). Data are derived from the US climatic divisions data set (Guttmann \& Quayle 1996) 
in the mid-1970s (e.g., Trenberth 1990). Such major variations in circulation have produced a highly variable surface climate.

\subsection{Extremes}

An extreme weather or climate event is one that lies outside the normal range of weather or climate for a particular place and, therefore, is infrequent or rare. Determining the historical frequency of regional extreme events is crucial to a regional climate change impact analysis because severe storms, heat waves, droughts, arctic air outbreaks and other such events have the potential to cause human and ecosystem hardship. Unfortunately, finding trends in the occurrence of extreme events in the historical climate records is difficult because extreme event data are seldom collected systematically. However, it can be concluded a priori that if climate change results in more extreme weather and climate then the current estimates of climate change impacts (which typically exclude this dynamic) will prove to be too optimistic and will therefore require more costly adaptive measures (Francis \& Hengeveld 1998).

Notwithstanding the lack of direct data on extreme events, it is possible to infer these events from daily climate data. The limited findings are at odds. For temperature, Baron (1995) found that the number of very hot summer days in the region appears to be decreasing. At the same time, he observed that the last frost of spring is coming progressively earlier and that there are fewer very cold winter days, i.e., winters are warming. Overall, he found the regional climate to be moderating. In contrast, using 13 stations in the Historical Climate Network (HCN) located in the MAR (Fig. 5), we discovered that from 1931 to 1997 the average number of days per year with maximum temperatures above $90^{\circ} \mathrm{F}\left(32.2^{\circ} \mathrm{C}\right)$ decreased linearly from roughly 23 to 16 (Fig. 6a). Over the same period, the average number of days per year with minimum temperatures less than $0^{\circ} \mathrm{F}$ $\left(-17.8^{\circ} \mathrm{C}\right)$ had a slight linear increase from 2.6 to 3.0 (Fig. 6b). Thus, we did not find the overall moderation observed by Baron.
Karl et al. (1996) found that extreme precipitation, expressed as the number of rainfall events exceeding 2 inches $(5.08 \mathrm{~cm})$ in $24 \mathrm{~h}$, has increased in the MAR during the 20th century. Karl \& Knight (1998), using another measure of extreme precipitation for the same century-long window, obtained similar results. These statistically significant findings mirror the overall increase in precipitation experienced in the region since 1895 (Fig. 4). However, using the $13 \mathrm{HCN}$ stations in the MAR, we found no overall linear trend (Fig. 6C). This finding appears to be in agreement with Kunkel et al. (1999; see their Figs. $4 \&$ 5), who also used data from 1931. Thus, the trend of extreme precipitation events in the region is unclear and requires further investigation.

Despite the ambiguity in the extreme short-duration temperature and precipitation findings, the region ap-

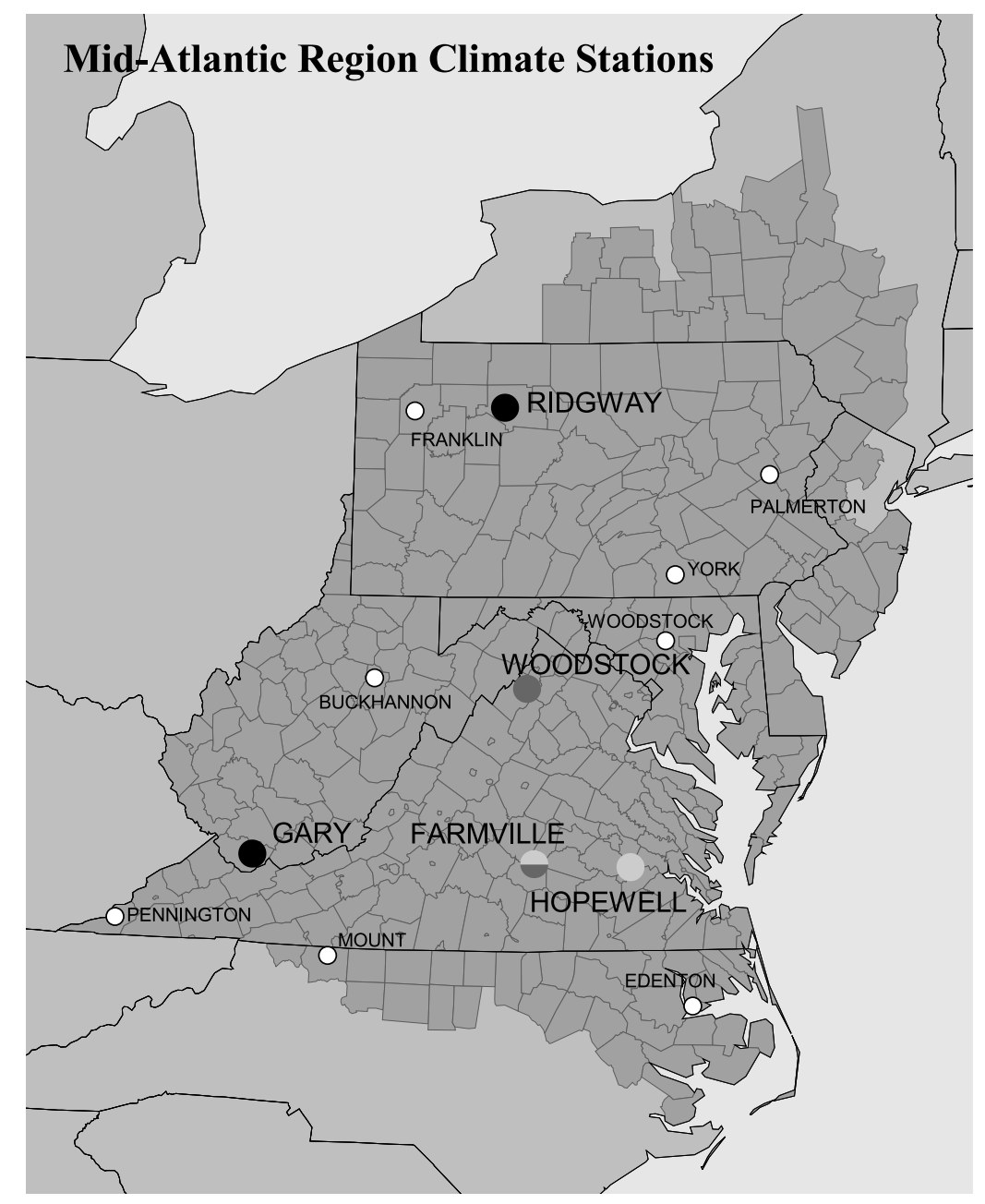

Fig. 5. Thirteen stations from the Historical Climate Network daily data set (T. Karl pers. comm.) used in the analysis of extreme daily events and of intraregional variation. Shading used for locations is keyed to the transects used in the intra-regional analysis 

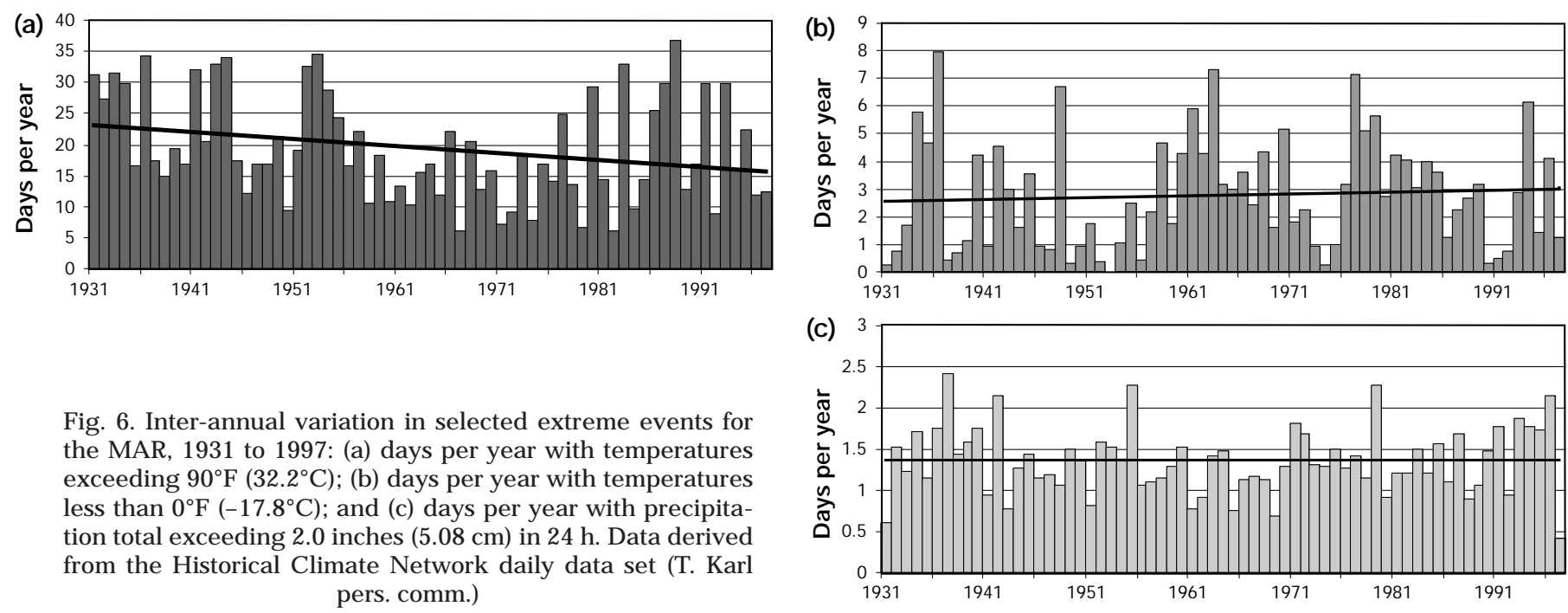

Fig. 6. Inter-annual variation in selected extreme events for the MAR, 1931 to 1997: (a) days per year with temperatures exceeding $90^{\circ} \mathrm{F}\left(32.2^{\circ} \mathrm{C}\right)$; (b) days per year with temperatures less than $0^{\circ} \mathrm{F}\left(-17.8^{\circ} \mathrm{C}\right)$; and (c) days per year with precipitation total exceeding 2.0 inches $(5.08 \mathrm{~cm})$ in $24 \mathrm{~h}$. Data derived from the Historical Climate Network daily data set ( $T$. Karl pers. comm.)

pears to be experiencing increasing inter- and intraannual swings in climate (Fig. 4). For example, the 3 coldest winters in the record occurred successively in 1976-77, 1977-78, and 1978-79 (Diaz \& Quayle 1980), while some of the warmest winters - all associated with EI Niño events-occurred in 1982-83, 1994-95, and 1997-98. The region has experienced several severe droughts in the last 2 decades, but the wettest year in more than a century was 1996 and the second wettest year was 1972. In most of the MAR, 3 of the snowiest winters were 1992-93, 1993-94, and 1995-96, while the EI Niño winters of 1994-95 and 1997-98 were 2 of the least snowy winters on record.

The MAR climate has also exhibited extreme variations within individual seasons and years. For instance, December 1989, the coldest December on record, was followed by the warmest J anuary-February in the books. Interestingly, these extremes of opposite sign canceled each other so that climatological winter 1989-90 was an average winter statistically. Precipitation has behaved similarly. The first half of 1998 was the wettest on record in many areas in the MAR and it appeared that calendar year 1998 was going to beat 1996 easily for the all-time wettest year. In spite of that, drought gripped the region during the second half of 1998, making it an average year statistically. Calendar year 1999 was the driest year on record in much of the MAR.

In sum, the limited record of weather and climate extremes in the region produces a mixed signal. There are conflicting indications of increasing moderation and increasing extremes on daily time scales and of increasing extremes in seasonal and interannual climate. More research is needed on this critical topic.

\subsection{Intra-regional variation}

Climatic transects across the region generally reflect the influences of latitude, elevation, and physiography. Temperatures decrease from the south (Fig. 7a,b), where temperatures are highest because of the relatively low latitude and the low elevations of the Piedmont physiographic province, to the north, where temperatures are lowest because both latitude and elevations are higher on the Appalachian Plateau. Temperatures also decrease from east to west (Fig. 8a,b) because elevations are lowest in the coastal plain and highest in the mountains.

Regional precipitation patterns are more complicated. The south-north transect (Fig. 7c) shows the influence of temperature and proximity to moisture when comparing the 2 more southerly stations. In this case, the station that is farther south and closer to the A tlantic Ocean has higher precipitation totals. In contrast, the third, northernmost station is cooler and removed from the ocean, but receives considerable precipitation from another mechanism-lake effect precipitation (Ellis \& Leathers 1997). The lake effect is weaker during zonal flow regimes, but has higher inter-annual variability; it is stronger with lower variability during meridional regimes. The east-west transect (Fig. 8c) is even more complex and is difficult to generalize.

Frequencies of extreme temperature events in the MAR are a function of latitude and elevation. Southerly (northerly) stations have far more (far fewer) days over $90^{\circ} \mathrm{F}\left(32.2^{\circ} \mathrm{C}\right)$, while northerly (southerly) stations have far more (far fewer) days less than $0^{\circ} \mathrm{F}\left(-17.8^{\circ} \mathrm{C}\right)$ (Fig. 9a,b, respectively). Similarly, low-elevation (eastern) stations have more very hot days and less very cold days than high-elevation (western) stations 

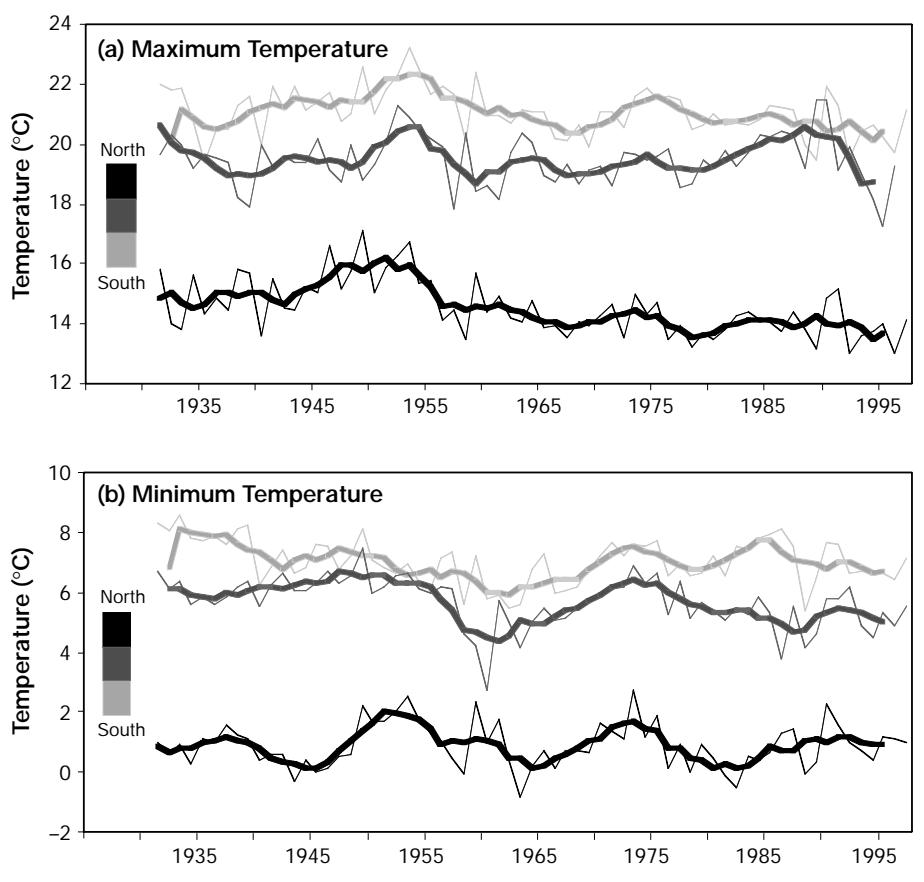

(Fig. 10a,b). Although the trends are less evident for extreme precipitation events, the same south-north and lowland-highland gradients appear in these data (Figs. 9c \& 10c, respectively).

\section{CLIMATE CHANGE SCENARIOS}

The second step in the 3-step process of climate change impact assessment involves applying pre-
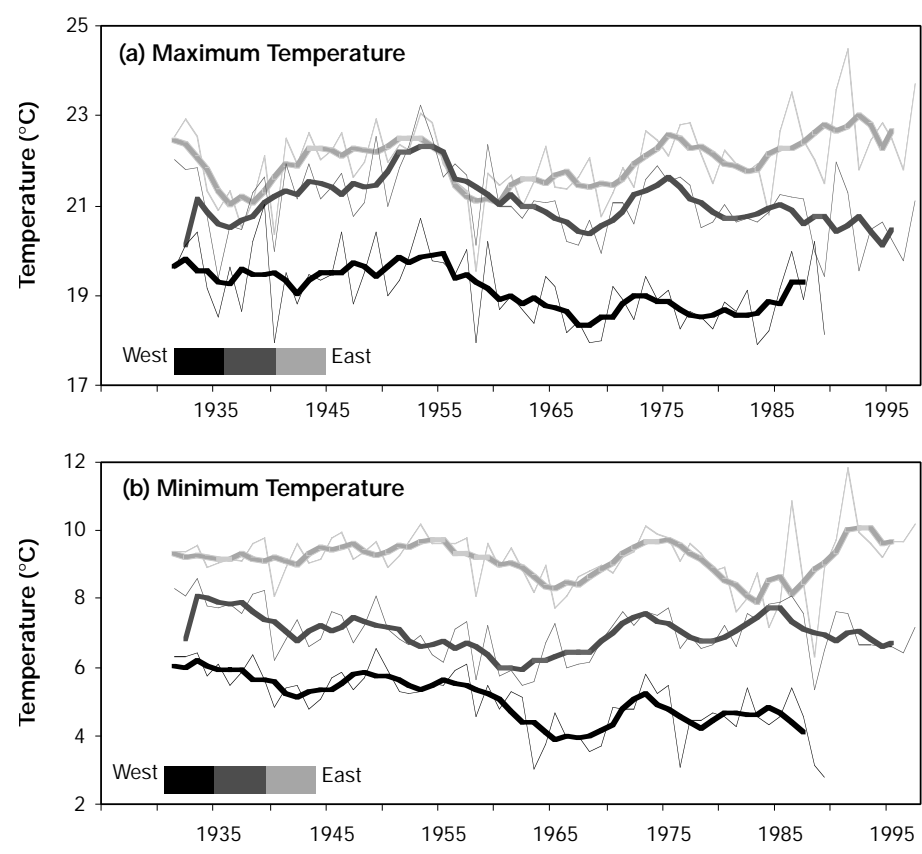

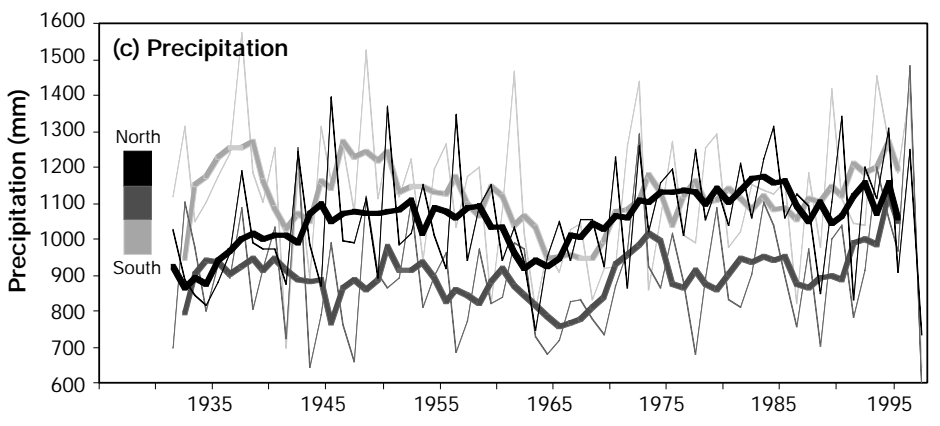

Fig. 7. A south-north transect in the MAR of (a) maximum temperature, (b) minimum temperature, and (c) total precipitation for various years starting in 1931 and concluding in 1997. The line shading here corresponds to the station shading shown in Fig. 5; the stations come from the Historical Climate Network daily data set (T. Karl pers. comm.)

scribed climate changes to the baseline projections of socio-economic and ecological variables outlined in Section 2 and detailed further in the following articles of this Special. The prescribed climate changes are presented in this section.

The MAR climate change scenarios are derived from 2 transient numerical models of the global climate system. The Hadley Centre for Climate Prediction and Research developed one model to simulate the global climate from 1860 to 1990 and then to estimate the

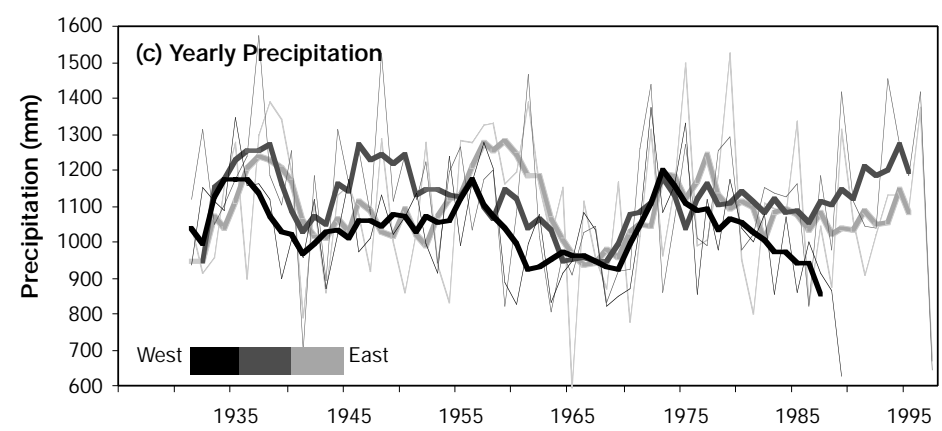

Fig. 8. An east-west transect in the MAR of (a) maximum temperature, (b) minimum temperature, and (c) total precipitation for various years starting in 1931 and concluding in 1997. The line shading here corresponds to the station shading shown in Fig. 5; the stations come from the Historical Climate N etwork daily data set (T. Karl pers. comm.) 


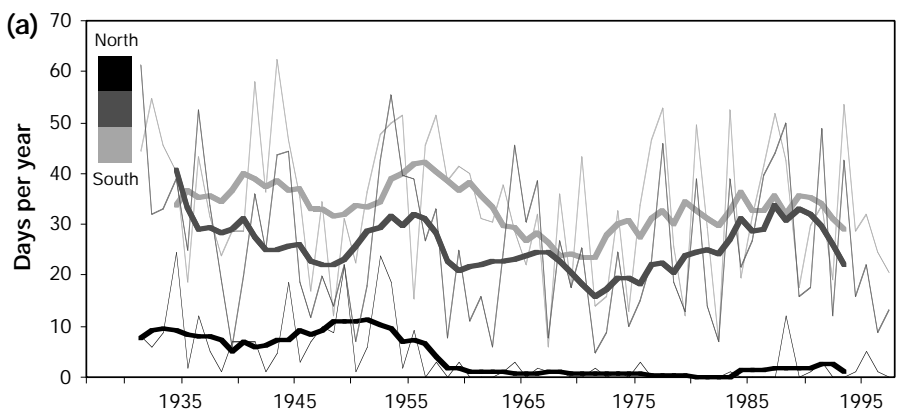

Fig. 9. Inter-annual variation in selected extreme events for the south-north transect of Fig. 7. (a) days per year with temperatures exceeding $90^{\circ} \mathrm{F}\left(32.2^{\circ} \mathrm{C}\right)$; (b) days per year with temperatures less than $0^{\circ} \mathrm{F}\left(-17.8^{\circ} \mathrm{C}\right)$; and (c) days per year with precipitation total exceeding 2.0 inches $(5.08 \mathrm{~cm})$ in $24 \mathrm{~h}$. Data derived from the Historical Climate Network daily data set (T. Karl pers. comm.)

global climate change for the period 1990 to 2099. The climate change experiment includes the effects of both atmospheric greenhouse gases (which increase global surface temperatures) and sulfate aerosols (which reduce temperatures in regions with high aerosol loading). In this experiment, carbon dioxide $\left(\mathrm{CO}_{2}\right)$ content of the atmosphere is increased by $1 \% \mathrm{yr}^{-1}$ over the 1990 values. The second model used in this assessment is from the Canadian Climate Centre (CCC). The CCC model simulates the global climate from 1850 to 1990

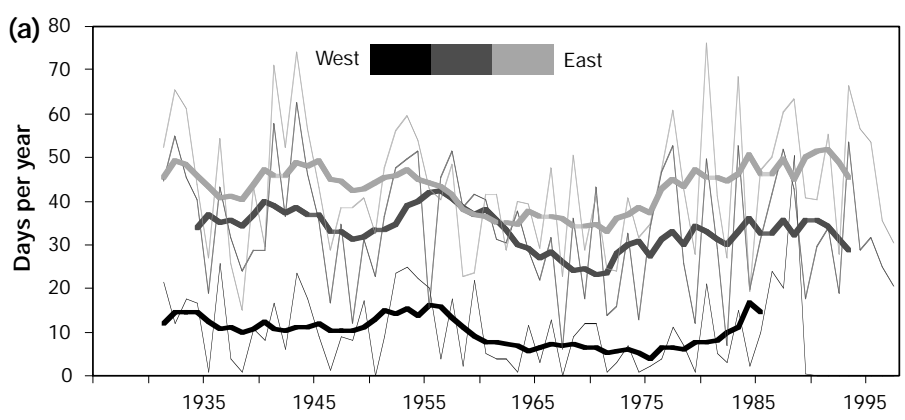

Fig. 10. Inter-annual variation in selected extreme events for the east-west transect of Fig. 8. (a) days per year with temperatures exceeding $90^{\circ} \mathrm{F}\left(32.2^{\circ} \mathrm{C}\right)$; (b) days per year with temperatures less than $0^{\circ} \mathrm{F}\left(-17.8^{\circ} \mathrm{C}\right)$; and (c) days per year with precipitation total exceeding 2.0 inches $(5.08 \mathrm{~cm})$ in $24 \mathrm{~h}$. Data derived from the Historical Climate Network daily data set (T. Karl pers. comm.)
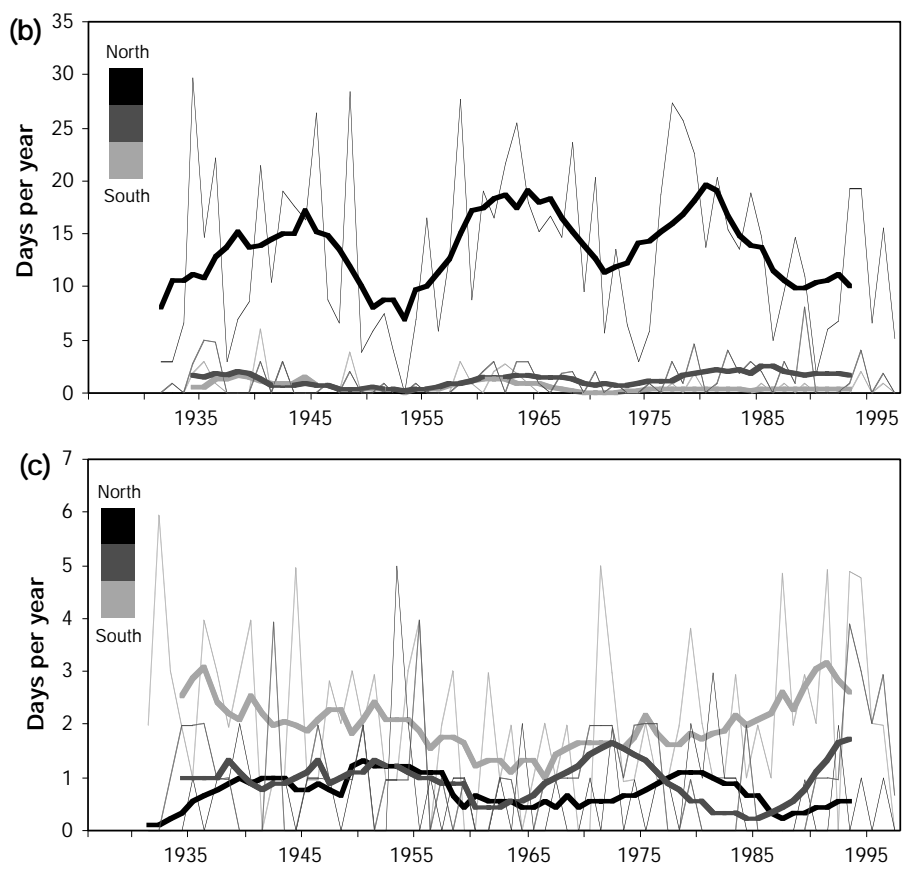

and then estimates the global climate from 1990 to 2100 , including aerosols and a $1 \% \mathrm{yr}^{-1}$ increase in $\mathrm{CO}_{2}$. Detailed descriptions of both models can be found in a number of publications. See, for example, Boer et al. (1992) for a discussion of the CCC model, Cullen (1993) and Mitchell et al. (1995) for a description of the Hadley Centre model, and Doherty \& Mearns (1999) for a comparison of the models.

Both models contain sophisticated representations of the physical processes that drive atmospheric dynamics,
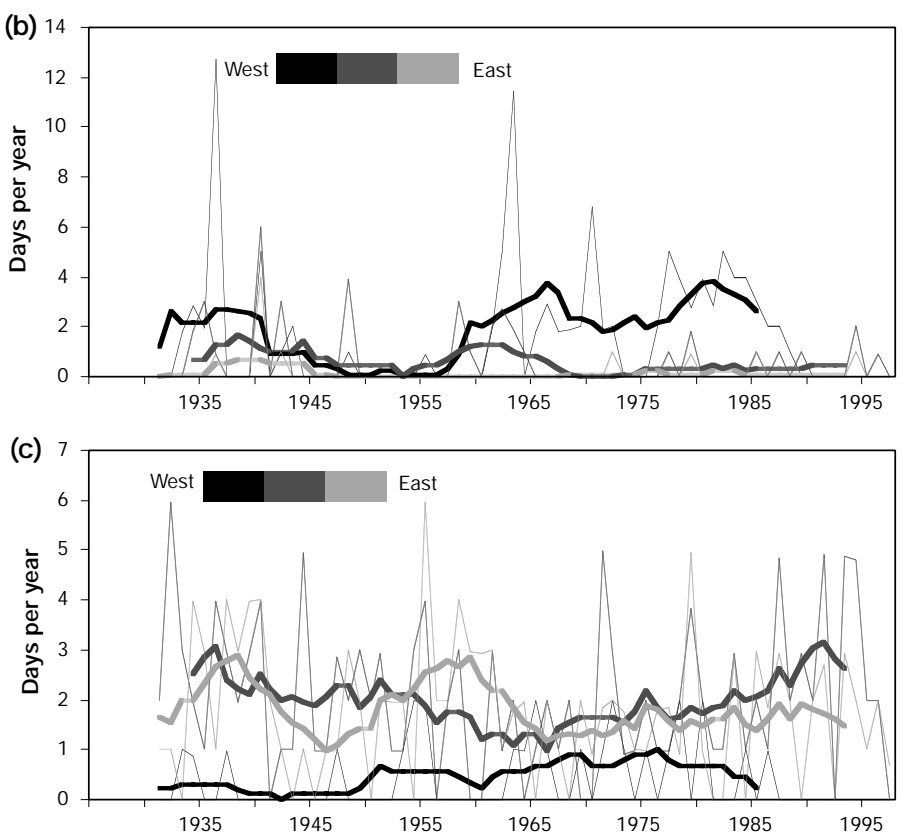
and both simulations are carried out with similar greenhouse gas and aerosol scenarios. Despite these similarities, the models produce significantly different results over the MAR, which simply highlights the uncertainty involved in using global models to infer a regional response to changing climate. These differences are characterized in Fig. 11. Here results for each model over the MAR for the coming century are compared to the model results for the baseline period 1984 to 1993 for maximum temperature, minimum temperature, and precipitation. The CCC model becomes increasingly warmer and drier than the Hadley Centre model over the course of the 21st century. The CCC model lacks realistic looking climate variations, while the Hadley Centre model time series look more like observed climate variations (Fig. 4). Finally, the CCC model maximum temperatures rise more than minimum temperatures; Hadley Centre model minimum temperatures rise more than maximum temperatures. Global mean maximum temperature, minimum temperature, and precipitation for both models (not shown) are similar to the regional-scale generalizations.

In sum, the 2 model scenarios depict very different climatic paths for the MAR and should therefore generate distinct scenarios for associated impacts on ecosystems and societies. There is considerable uncertainty in the regional details of any global climate model and, in some respects, these 2 models can be regarded as spanning the range of possible climate change scenarios for the MAR. Additional modeling studies (see below) are more consistent with the Hadley Centre model results. Thus the Hadley Centre results are used in the following discussion of likely climate change scenarios.

In nearly all of the analyses performed in this Special, the decades 2025 to 2034 and 2090 to 2099 were extracted from the transient climate model runs to assess the impacts of potential climate change in the MAR. We estimate the spatial distribution of climate change over the MAR by interpolating the model results ('future climate') to a finer regional spatial resolution using the VEMAP grid (Kittel et al. 1995, Rosenbloom \& Kittel 1999), and noting the differences between these results and a measure of present climate. For purposes of illustration, Fig. 12 shows the results of this procedure, for 1 model (Hadley Centre) and 1 time slice (2025 to 2034) only, compared to the region's present climate, represented by the years 1984 to 1993.
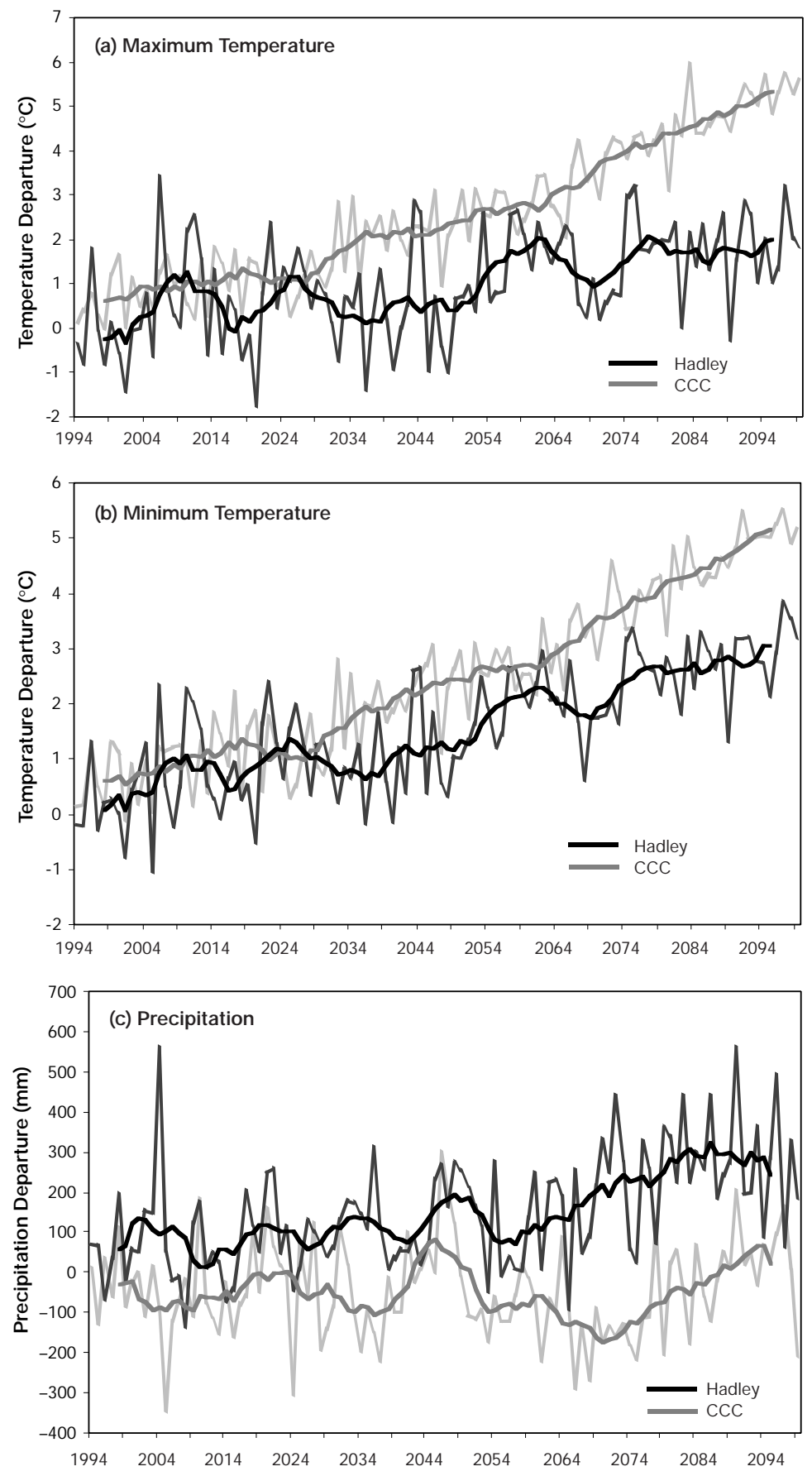

Fig. 11. (a) Hadley Centre and Canadian Climate Centre model departures from the 1984 to 1993 values derived by the models, averaged over the MAR for (a) mean annual maximum temperature $\left({ }^{\circ} \mathrm{C}\right)$, (b) mean annual minimum temperature $\left({ }^{\circ} \mathrm{C}\right)$, and (c) mean annual precipitation total $(\mathrm{mm})$. Smoothed lines represent 9 yr running means

In particular, estimated climate changes (J anuary and J uly mean maximum and minimum temperatures, and mean precipitation totals) are shown in Fig. 12. This figure suggests that much of the change in maximum temperatures will occur in the summer, with the 


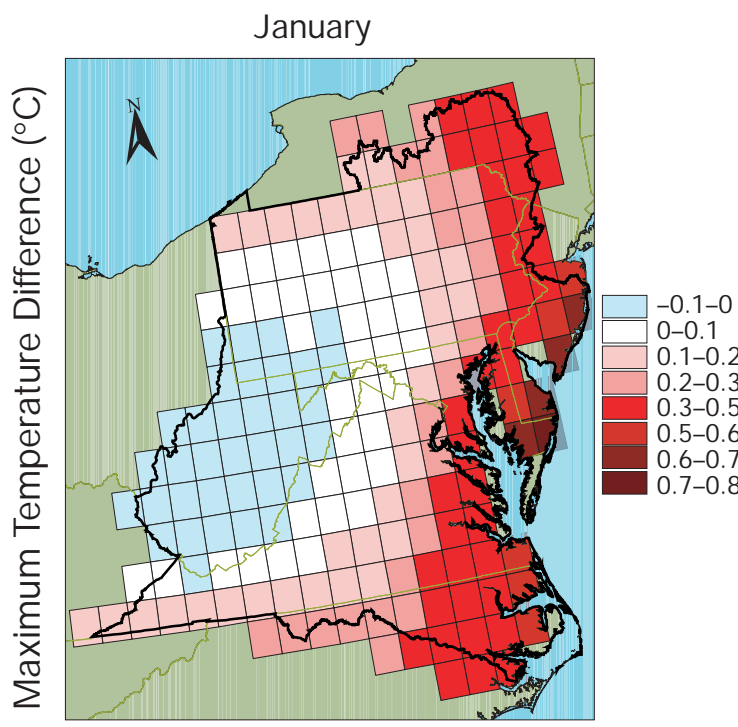

a
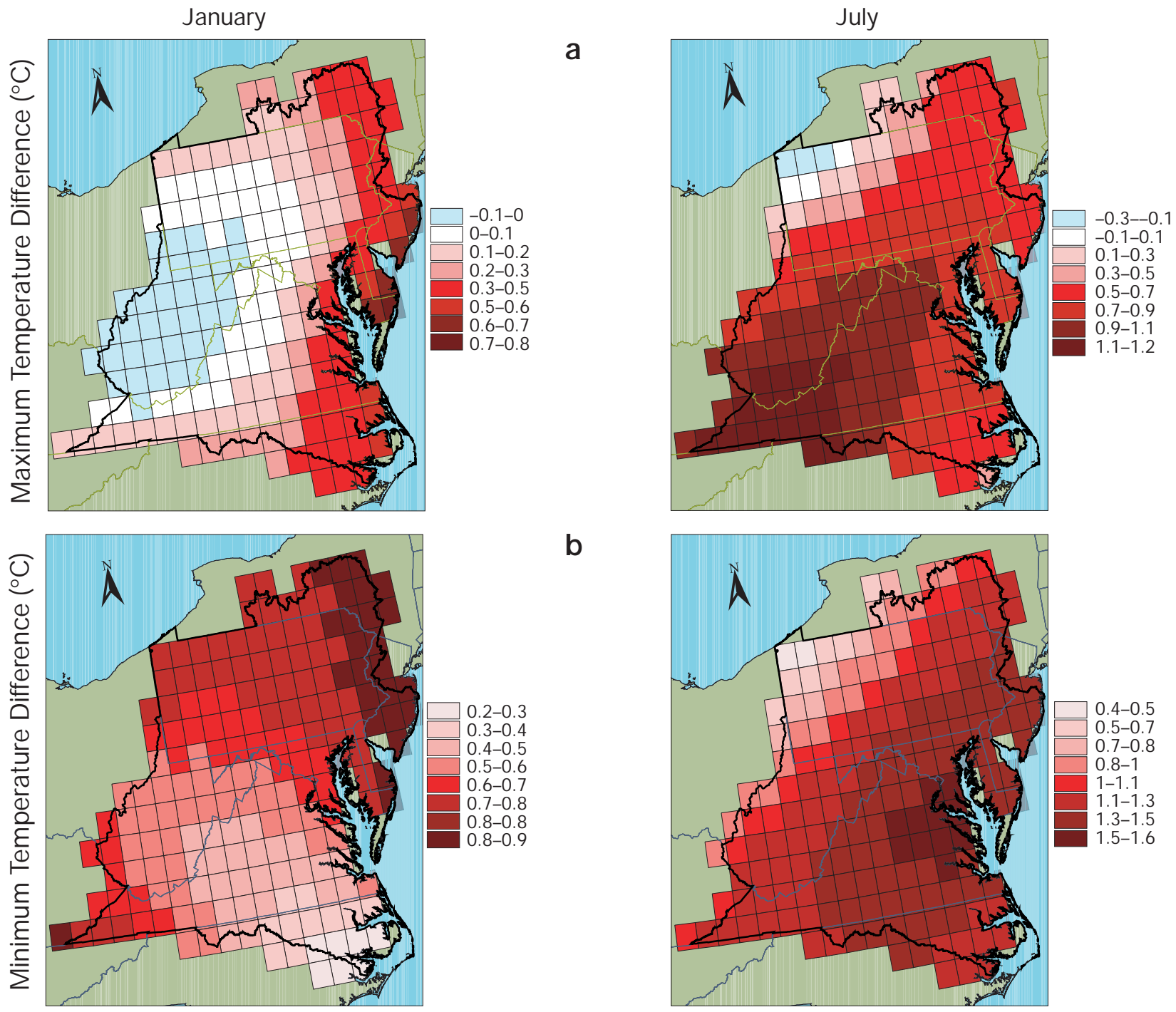

b
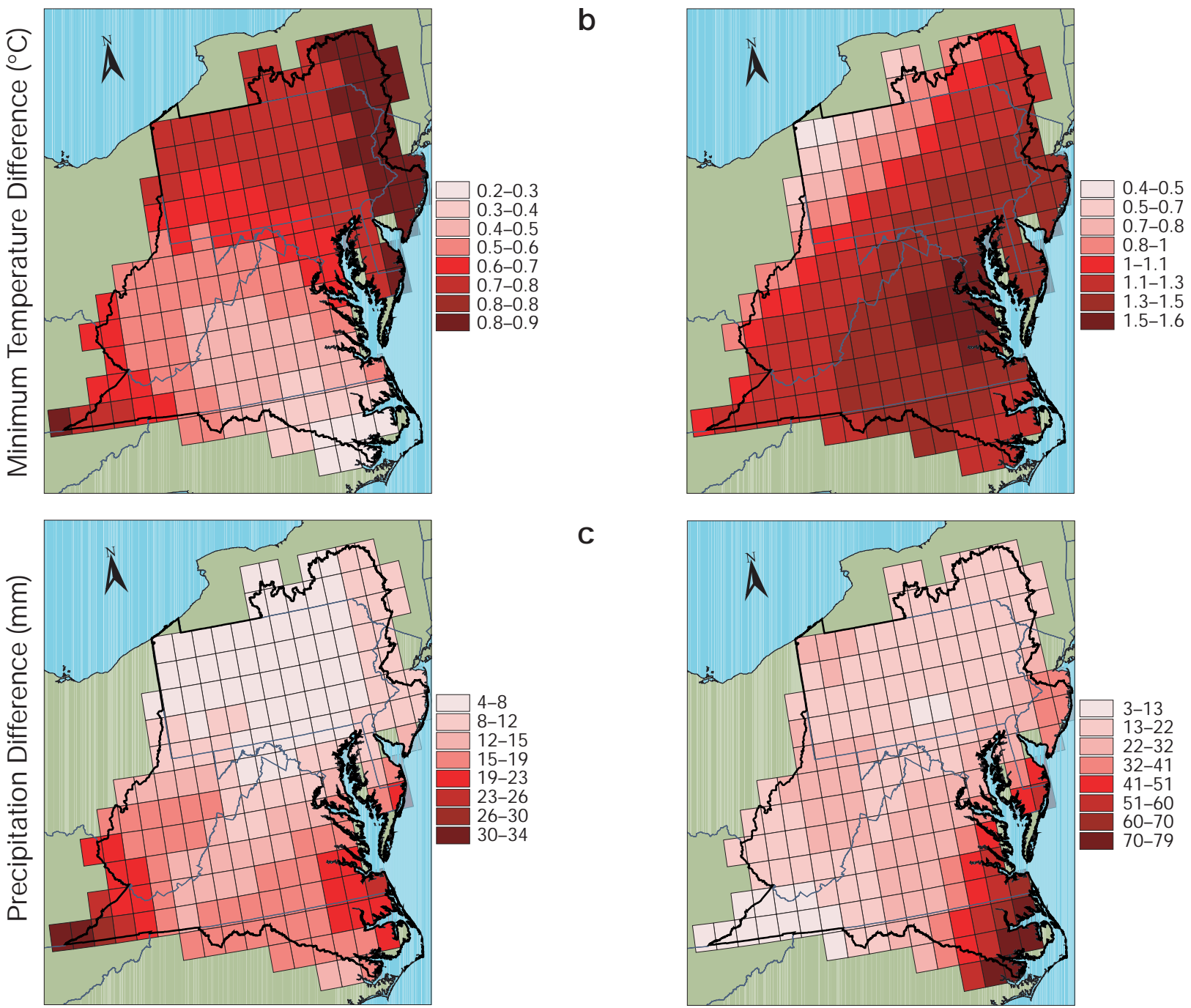

C

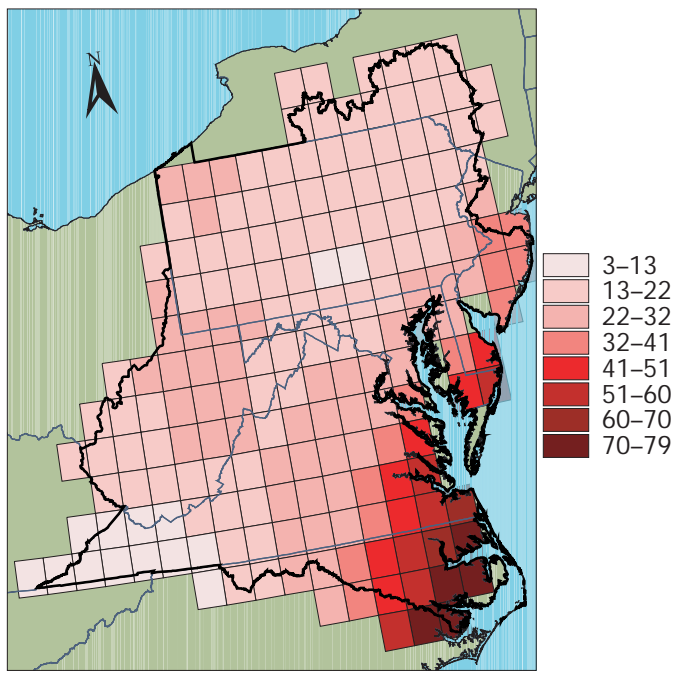

Fig. 12. Difference between future (2025 to 2034) and present (1984 to 1993) J anuary (left) and J uly (right) mean values for (a) maximum temperature, (b) minimum temperature, and (c) precipitation (using the Hadley Centre model) 
greatest changes being in the southwest and central parts of the region. The minimum temperature maps reveal a somewhat different pattern. Higher summer temperatures occur in the south and east. In winter, increases in maximum temperatures are confined to the eastern edge of the region, while maximum temperatures are actually lowered in the west. This would imply slightly lower daytime temperatures in the western part of the region compared to the present. Minimum temperatures increase across the whole region in winter, with the gratest increase being to the north. Comparing the model results for precipitation in 1984 to 1993 and 2025 to 2034 shows a slight uniform increase in J anuary. Precipitation also increases across the whole region in July, but with the greatest increases being in the southeast.

These results are broadly consistent with 2 earlier climate downscaling studies that covered portions of the MAR, but used the GENESIS global climate model. Both GENESIS experiments were equilibrium experiments in which the atmospheric $\mathrm{CO}_{2}$ concentration is doubled and the climate model reaches an equilibrium climate state. The results of the doubled $\mathrm{CO}_{2}$ model are then compared to the results of the same model using late 20th century atmospheric $\mathrm{CO}_{2}$ values. The models did not include the effects of sulfates. One study used a numerical regional climate model in conjunction with GENESIS (] enkins \& Barron 1997). Similar to the Hadley Centre scenario, it produced an increase in annual precipitation, but the greater increase was in winter rather than summer. The second study employed a later version of GENESIS and used an empirical climate downscaling technique (Crane \& Hewitson 1998). The results were very similar to the Hadley Centre scenario; it found a large increase in precipitation that was concentrated in the summer months and that had the largest changes occurring to the south (but over the southwestern mountains instead of the southeastern coastal plain).

\section{CONCLUSIONS}

A climate change impact assessment is defined in part by the baseline account of the area in question and by the prescribed climate changes to be imposed on the area. For the MAR, a distinct east-west landform gradient contributes to the character and distribution of socio-economic and ecological variables potentially at risk to climate change. For example, the ecologically and economically valuable estuaries in the Coastal Plain are threatened by pollution from an upstream human population growing in size and income, on both aggregate and per capita bases. While there are important differences in climate within the region, the overall regional climate has become warmer and wet- ter over the past century. This trend is expected to continue, according to 2 general circulation models. Defining the significance of baseline variable changes in response to climate changes constitutes the final step of the climate change impacts assessment process. This step is addressed for the US MAR on a sectorspecific basis in the remaining papers of this Special.

Acknowledgements. We would like to thank the researchers and Advisory Committee of the Mid-Atlantic Regional Assessment for their help and encouragement during the preparation of this paper. Primary support came from the US EPA Office of Policy, Planning and Evaluation Cooperative Agreement CR-824369 and the US EPA Office of Research and Development Cooperative Agreement CR-826544. Additional support was provided by the US National Science Foundation Human Dimensions of Global Change Grant SBR9521952 and the US EPA STAR Program Grant R82-4807. The views expressed here are not necessarily those of the sponsoring agencies.

\section{LITERATURE CITED}

Balling RC J r, Lawson M P (1982) Twentieth century changes in winter climatic regions. Clim Change 4:57-69

Baron WR (1995) Historical climate records from the northeastern United States, 1640 to 1900. In: Bradley RS, J ones PD (eds) Climate since AD 1500. Routledge, London, p 74-91

Boer GJ , M cFarlane NA, Lazare M (1992) Greenhouse gasinduced climate change simulated with the CCC secondgeneration general circulation model. J Clim 5:1045-1077

Bureau of the Census (1997) 1997 statistical abstract of the United States. US Bureau of the Census, Washington, DC (accessed: March 23, 2000); available at http://www.census.gov/prod/3/97pubs/97statab/cc97stab.htm

Bureau of the Census (1998a) Historical national population estimates. US Bureau of the Census, Washington, DC (accessed: March 23, 2000); available at http://www.census.gov/population/estimates/nation/popclockest.txt

Bureau of the Census (1998b) State and metropolitan area data book 1997-98, 5th edn. US Bureau of the Census, Washington, DC

Carter TR, Parry ML, Harasawa H, Nishioka S (1994) IPCC technical guidelines for assessing climate change impacts and adaptations. Department of Geography, University College London, and the Center for Global Environmental Research, National Institute for Environmental Studies, J apan (accessed: March 26, 2000); Available from IPCC Secretariata at http://www.ipcc.ch/pub/pub.htm

Crane RG, Hewitson BC (1998) Doubled $\mathrm{CO}_{2}$ precipitation changes for the Susquehanna Basin: downscaling from the GENESIS general circulation model. Int J Climatol 18: 65-76

Cronin T (1997) Perspectives on current impacts and adaptation to climate variability in the Mid-Atlantic Region. Oral presentation at the Workshop on Climate Change Impacts in the Mid-Atlantic Region, The Pennsylvania State University, University Park, PA, September 9-11

Cronin T, Willard D, Karlsen A, Ishman S, Verardo S, MCGeehin J, Kerhin R, Homes C, Colman S, Zimmerman A (2000) Climatic variability in the eastern United States over the past millennium from Chesapeake Bay sediments. Geology 28:3-6 
Cuff DJ, Young WJ, Muller EK, Zelinsky W, Abler RF (eds) (1989) The atlas of Pennsylvania. Temple University Press, Philadelphia

Cullen MJ P (1993) The unified forecast/climate model. M eteorological Mag 122:81-95

Diaz HF, Quayle RG (1980) An analysis of the recent extreme winters in the contiguous United States. M on Weather Rev 108:687-699

Doherty ER, M earns LO (1999) A comparison of simulations of current climate from two coupled atmosphere-ocean global climate models against observations and evaluation of their future climates. Report to the National Institute for Global Environmental Change (NIGEC), National Center for Atmospheric Research, Boulder, CO

Ellis AW, Leathers DJ (1997) A synoptic climatological approach to the analysis of lake-effect snowfall: potential forecasting applications. Weather Forecast 11:216-229

EPA (1997) An ecological assessment of the United States M id-Atlantic Region: a landscape atlas. Office of Research and Development, US Environmental Protection Agency, Document \#EPA/600/R-97/130, Washington, DC

Fisher A, N eff R, Barron EJ (2000) The M id-Atlantic Regional Assessment: motivation and approach. Clim Res 14:153-159

Francis D, Hengeveld H (1998) Extreme weather and climate change. Climate Change Digest Special No. 2, Atmospheric Environment Service, Environment Canada, Downsview, ONT

Guttman NB, Quayle RG (1996) A historical perspective of US climate divisions. Bull Am M eteorol Soc 77:293-303

J enkins GS, Barron EJ (1997) Global climate model and coupled regional climate model simulations over the eastern United States: GENESIS and RegCM 2 simulations. Global Planetary Change 15:3-32

Kalnicky RA (1974) Climatic change since 1950. Ann Assoc Am Geogr 64:100-112

Karl TR, Knight RW (1998) Secular trends of precipitation amount, frequency, and intensity in the United States. Bull Am M eteorol Soc 79:231-241

Karl TR, Knight RW, Easterling DR, Quayle RG (1996) Indices of climate change for the United States. Bull Am M eteorol Soc 77:279-292

Kittel TGF, Rosenbloom NA, Painter TH, Schimel DS, VEM AP M odeling Participants (1995) The VEMAP integrated database for modeling United States ecosystem/ vegetation sensitivity to climate change. J Biogeogr 22: 857-862

Kunkel KE, Andsager K, Easterling DR (1999) Long-term trends in extreme precipitation events over the conterminous United States and Canada. J Clim 12:2515-2527

MARA (1999) Landsat Thematic M apper data from the USGS EROS Data Center. The Mid-Atlantic Regional Assessment (MARA) of Climate Change Impacts team, The Pennsylvania State University (accessed: M arch 27, 2000); available at http://www.essc.psu.edu/mara/region/physiography.html

Marsh B, Lewis PF (1995) Landforms and human habitat. In: Miller EW (ed) A geography of Pennsylvania. Penn State University Press, University Park, p 17-43

Mitchell J FB, J ohns TC, Gregory J M, Tett S (1995) Climate response to increasing levels of greenhouse gases and sulphate aerosols. Nature 376:501-504

NOAA (1998) Our crowded shores: balancing growth and resource protection. CD-ROM produced by the US National Oceanic and Atmospheric Administration National Ocean Service and InterN etwork M edia, Incorporated

NPA (1998a) Regional economic projection series. NPA Data Services, Inc, Washington, DC

NPA (1998b) Sources and methods of preparation of the 1998 regional economic projection series data base. NPA Data Services, Inc. Washington, DC

Rogers CE, M CCarty J P (2000) Climate change and ecosystems of the Mid-Atlantic Region. Clim Res 14:235-244

Rose A, Cao Y, Oladosu G (2000) Simulating the economic impacts of climate change in the Mid-Atlantic Region. Clim Res 14:175-183

Rosenbloom N, Kittel TGF (1999) A user's guide to the VEM AP Phase I database. Climate System M odeling Program, University Corporation for Atmospheric Research, and the Ecosystem Dynamics and the Atmosphere Section, Climate and Global Dynamics Division, National Center for Atmospheric Research, Boulder, CO, (accessed: March 23, 2000); available at http://www.cgd.ucar.edu/ vemap/users_guide.html

Shane M, Roe T, Gopinath M (1998) U.S. agricultural growth and productivity: an economywide perspective. US Department of Agriculture, Agricultural Economic Report No. 758, Washington, DC

Trenberth KE (1990) Recent observed interdecadal climate changes in the Northern Hemisphere. Bull Am Meteorol Soc 71:988-993

Yarnal B, Leathers DJ (1988) Relationships between interdecadal and interannual climatic variations and their effect on Pennsylvania climate. Ann Assoc Am Geogr 78: 624-641 